\title{
Hábitat 3E: Una visión alternativa para los Conjutos Larga Estadía de Adultos Mayores
}

\author{
Pablo Navarrete H. / Profesor Guía: Eduardo Lyon R.
}

El proyecto busca explorar una metodología para integrar Conjuntos de Viviendas de Adulto Mayor a entornos con redes de servicios, incorporando los servicios faltantes en una solución de equilibrio en tres escalas: Contexto, conjunto y vivienda.

\section{Mix-programático según inserción}

Para esto se trabajó en la comuna de mayor densidad de adultos mayores. Se tomaron 6 factores de entorno (salud, seguridad, consumo diario, accesibilidad, deportes y recreación, áreas verdes) determinándose su ubicación y cobertura. Éstos se contrastaron con la disponibilidad de terrenos, escogiéndose el con mayor cobertura. Quedaron fuera de la cobertura los factores de recreación, deporte y áreas verdes, que se insertaron en la propuesta.

Viabilidad y dimensión adecuada de los programas

Se modeló una ecuación de 4 incógnitas, relacionando $\mathrm{m}^{2}$ de servicios a incluir, $\mathrm{m}^{2}$ de terreno disponible, valores $/ \mathrm{m}^{2}$ de construcción y al $15 \%$ de rentabilidad inmobiliaria. Esto determinó los metrajes a construir.

\section{Morfología del conjunto}

Soleamiento: El objetivo fundamental fue conseguir el mayor soleamiento de las viviendas, evaluándose distintos modelos de distribución; el esquema de peineta resultó ser el más adecuado. Éste fue optimizado, al quebrar los volúmenes para aumentar el ángulo de soleamiento norte, así como, longitudinalizando y distribuyendo sólo una viviendas por crujida.

Programación: Un esquema de relaciones posibles en forma de juego de fichas, busca dar una ubicación distribuida y diversa al programa en el conjunto, buscando optimizar distancias, diversificar los recorridos y fomentar la interacción social

Éste se concreta desfasando las viviendas y dejando vacíos desde simple hasta cuádruple altura, en donde se ubican las fichas programáticas siguiendo el cuadro de relaciones. Cada uno constituye un paisaje de diseño único, inmediato a las viviendas o recorridos.

\section{Imagen del Conjunto}

Se explota la imagen de área verde, debido a la falta de imágenes verdes en el contexto y la gran cantidad de $\mathrm{m}^{2}$ de este tipo a integrar. Éste resulta además ser el principal mecanismo de control térmico del edificio.

Para esto se seleccionaron enredaderas caducas de 7 colores que controlan la entrada del sol según las estaciones del año.

\section{La vivienda}

Se diseñaron 4 viviendas temáticas en 3 tamaños, basadas en un espacio único compartimentable con énfasis de uno de los programas estándar: cocina, terraza, dormitorio, jardín, cumpliendo con los estándares internacionales de confort y seguridad para el adulto mayor.
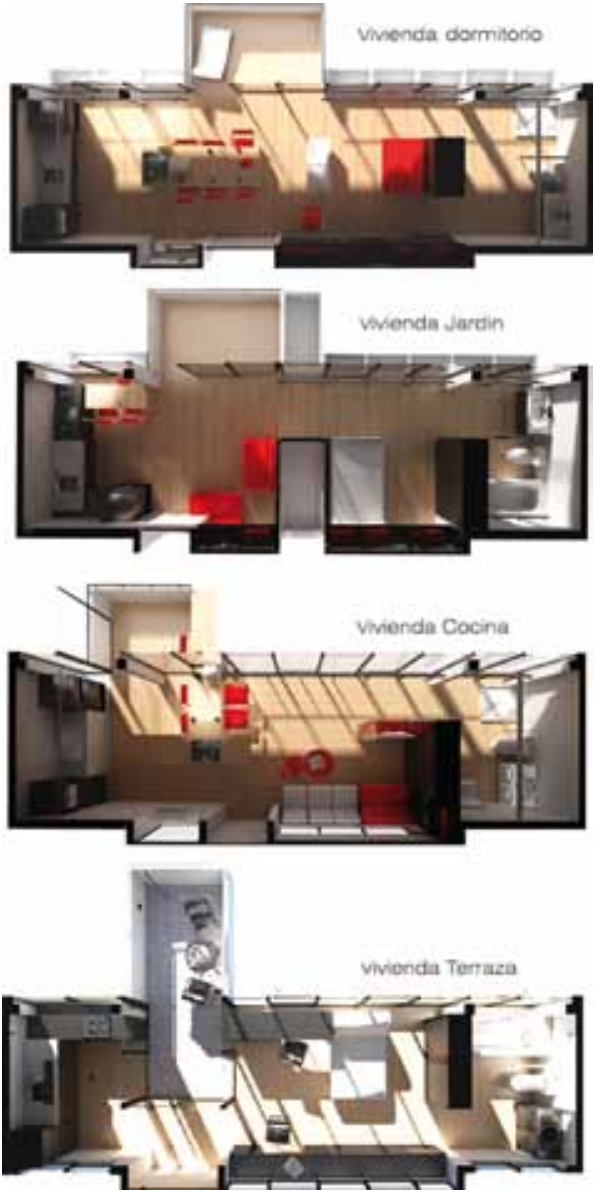

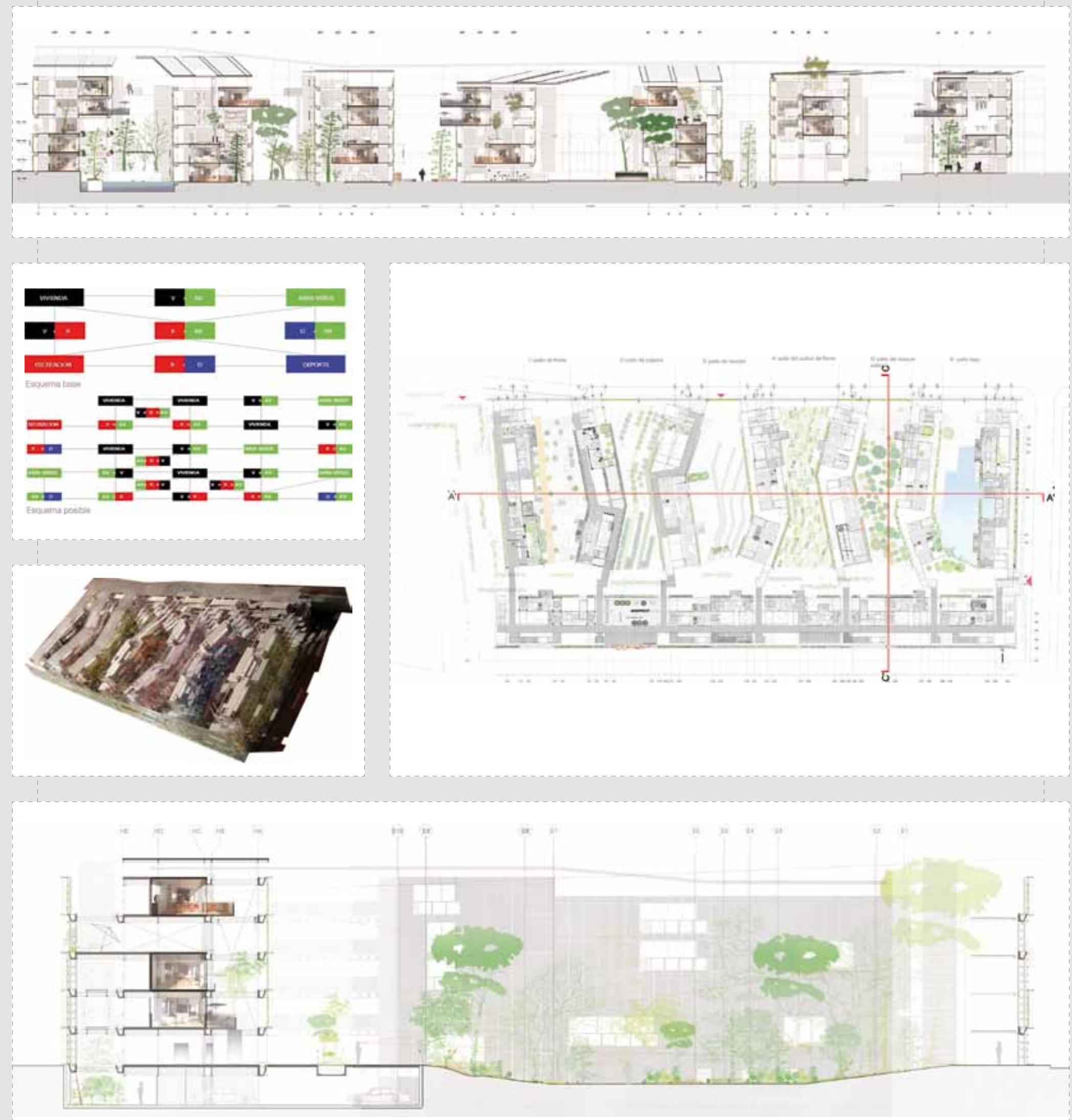